University of Nebraska - Lincoln

DigitalCommons@University of Nebraska - Lincoln

Virology Papers

Virology, Nebraska Center for

$10-1-2004$

\title{
Detection and Quantitation of Bovine Respiratory Syncytial Virus Using Real-Time Quantitative RT-PCR and Quantitative Competitive RT-PCR Assays
}

\author{
Jenna Achenbaum \\ University of Nebraska-Lincoln \\ Christina L. Topliff \\ University of Nebraska-Lincoln, ctopliff2@unl.edu \\ Ventzislav B. Vassilev \\ University of Nebraska-Lincoln \\ Ruben O. Donis \\ University of Nebraska-Lincoln, rdonis@emory.edu \\ Kent M. Eskridge \\ University of Nebraska-Lincoln, keskridge1@unl.edu \\ See next page for additional authors
}

Follow this and additional works at: https://digitalcommons.unl.edu/virologypub

Part of the Virology Commons

Achenbaum, Jenna; Topliff, Christina L.; Vassilev, Ventzislav B.; Donis, Ruben O.; Eskridge, Kent M.; and Kelling, Clayton L., "Detection and Quantitation of Bovine Respiratory Syncytial Virus Using Real-Time Quantitative RT-PCR and Quantitative Competitive RT-PCR Assays" (2004). Virology Papers. 110.

https://digitalcommons.unl.edu/virologypub/110

This Article is brought to you for free and open access by the Virology, Nebraska Center for at DigitalCommons@University of Nebraska - Lincoln. It has been accepted for inclusion in Virology Papers by an authorized administrator of DigitalCommons@University of Nebraska - Lincoln. 


\section{Authors}

Jenna Achenbaum, Christina L. Topliff, Ventzislav B. Vassilev, Ruben O. Donis, Kent M. Eskridge, and Clayton L. Kelling 
Published in Journal of Virological Methods 121:1 (October 2004), pp. 1-6; doi 10.1016/j.jviromet.2004.05.004

Copyright (C) 2004 Elsevier B.V. Used by permission. http://www.sciencedirect.com/science/journal/01660934

A contribution of the University of Nebraska Agricultural Research Division, Lincoln, NE 68583, USA.

Submitted November 4, 2003; revised May 6, 2004; accepted May 10, 2004; published online August 4, 2004.

\title{
Detection and Quantitation of Bovine Respiratory Syncytial Virus Using Real-Time Quantitative RT-PCR and Quantitative Competitive RT-PCR Assays
}

\author{
Jenna E. Achenbach, Christina L. Topliff, Ventzislav B. Vassilev, \\ Ruben O. Donis, Kent M. Eskridge,* and Clayton L. Kelling
}

\author{
Department of Veterinary and Biomedical Sciences, University of Nebraska-Lincoln, Lincoln, NE 68583-0905, USA \\ * Department of Biometry, University of Nebraska-Lincoln, Lincoln, NE 68583-0905, USA \\ Corresponding author-C. L. Kelling, tel 402 472-3040, fax 402 472-9690, email ckelling@unl.edu
}

\begin{abstract}
A single tube, fluorogenic probe-based, real-time quantitative reverse transcription-polymerase chain reaction (Q-RT-PCR) assay was developed for detection and quantitation of bovine respiratory syncytial virus (BRSV) using BioRad's iCycler iQ ${ }^{\mathrm{TM}}$. Real-time Q-RT-PCR was compared with quantitative competitive RT-PCR (QC-RT-PCR) and viral titers. Viral mRNA levels were measured in BRSV-infected bovine turbinate cell lysate harvested at eight time points $(1.5,6,12,24,36,48,60,72 \mathrm{~h})$ post-infection. A homologous BRSV cRNA standard was used for quantitation of the mRNA by plotting a standard curve of cycle threshold (Ct) values versus standard 10-fold dilutions of cRNA of known concentrations. Detection as low as 171 copies/ $\mu 1$ of standard BRSV cRNA was possible. For QC-RT-PCR, a competitor RNA molecule having a deletion was designed and used for quantitation of the BRSV viral mRNA. The results of real-time Q-RT-PCR and QC-RT-PCR assays showed a positive correlation. Real-time Q-RT-PCR was a sensitive, specific, rapid, and efficient method that eliminates the post-PCR processing steps when compared to QC-RT-PCR. Quantitation of BRSV using real-time Q-RT-PCR will have application in studies aimed at understanding the pathogenesis of BRSV.
\end{abstract}

Keywords: Real-time quantitative RT-PCR; Quantitative competitive RT-PCR; iCycler; Bovine respiratory syncytial virus

\section{Introduction}

Bovine respiratory syncytial virus (BRSV) is a ubiquitous respiratory pathogen of cattle, which contributes to causation of bovine respiratory disease complex. BRSV belongs to the genus Pneumovirus and family Paramyxoviridae (Murphy et al., 1995), and is closely related to human respiratory syncytial virus (HRSV) (Lerch et al., 1989). HRSV causes respiratory disease in young children, the elderly and in individuals that are immunocompromised. Respiratory syncytial virus (RSV) has a single-stranded, negative-sense RNA that is approximately $15.2 \mathrm{kbp}$ in length. The viral genome is transcribed into 10 subgenomic RNA's, which encode for 11 proteins (Huang and Wertz, 1982).

Laboratory diagnostic tests for BRSV include virus isolation, histopathologic examination, enzyme-linked immunosorbent serum assay (ELISA) and reverse transcription-polymerase chain reaction (RT-PCR) procedures. While ELISAs are sensitive and specific (Hazari et al., 2002 and West et al., 1998), they require use of viral protein specific antibodies for detection. RT-PCR has been used for detection of BRSV and has proven to be more sensitive and rapid than virus isolation, indirect immunofluorescence, enzyme immunosorbent assay, and histopathologic examination (Oberst et al., 1993a and Oberst et al., 1993b; Valarcher et al., 1999).

While RT-PCR can be used to detect specifically BRSV, it cannot be used to determine the total amount of viral mRNA present in cells or tissue. This can be achieved using quantitative RT-PCR (Q-RT-PCR). Realtime Q-RT-PCR involves use of an external standard to create a standard curve to which results of assays of unknown samples can be compared. Real-time Q-RT-PCR 
is a rapid and sensitive method that can be used to accurately detect and quantify viral mRNA of BRSV-infected cell culture and tissues.

Quantitative competitive RT-PCR (QC-RT-PCR) uses an internal competitor that differs in size from the target, by creating a deletion or insertion and uses the same primers as the target, leading to equal amplification efficiencies and equal competition to determine the amount of mRNA present in the unknown sample.

This study describes, for the first time, the use of realtime Q-RT-PCR to detect and quantify viral mRNA in cell cultures infected with BRSV. This method was compared to QC-RT-PCR and virus titration.

\section{Materials and methods}

\subsection{Cells and virus}

Bovine turbinate (BT) cells (USDA, Animal and Plant Health Inspection Service- Center of Veterinary Biologics, Ames, IA) were infected in duplicate with BRSV strain 236-652 (Brodersen, B. and Kelling, C., 1998) using a multiplicity of infection of 0.05 . Viral inoculum $(0.8 \mathrm{ml} /$ well) was allowed to adsorb to BT cells in 6-well tissue culture plates for $1.5 \mathrm{~h}$ on a rocking platform at $37^{\circ} \mathrm{C}$. The viral inoculum was removed and replaced with $3 \mathrm{mls}$ Dulbecco's modified eagle medium (DMEM) (Invitrogen, Carlsbad, CA) supplemented with 2\% horse serum (Hyclone, Logan, UT). The virus-infected cells were incubated at $37^{\circ} \mathrm{C}, 5 \% \mathrm{CO}_{2}$, harvested at 1.5 , $6,12,24,36,48,60$, and $72 \mathrm{~h}$ post-infection, and stored at $-80^{\circ} \mathrm{C}$. Samples were then thawed on ice, vortexed and aliquoted into $1 \mathrm{ml}$ Wheaton cryule vials (Wheaton, Millville, NJ) and stored at $-80^{\circ} \mathrm{C}$ until used for RNA extraction.

\subsection{RNA extraction}

Total RNA was extracted in duplicate from the cell lysate of two separate BRSV-infected cell cultures at each time point using TRIZOL ${ }^{\circledR}$ LS reagent (Invitrogen, Carlsbad, CA) according to the manufacturer's recommendations. Extracted RNA was stored in $75 \%$ ethanol at $-80{ }^{\circ} \mathrm{C}$ until used. Prior to use, RNA was pelleted, dried, and resuspended in $10 \mu \mathrm{l}$ diethylpyrocarbonate-treated water and used immediately.

\subsection{Virus titration}

Virus was diluted serially, 10 -fold $\left(10^{-1}-10^{-7}\right)$ in DMEM, and each dilution of virus was aliquoted into each of 8 wells/dilution ( $50 \mu \mathrm{l} /$ well), of a 96-well tissue culture plate. To each well, a $100 \mu \mathrm{l}$ suspension of BT cells $(2 \times$ $10^{4}$ cells $\left./ \mu \mathrm{l}\right)$, in DMEM supplemented with $3 \%$ horse serum, 1.5X gentamicin (Sigma, St. Louis, MO) and 1.5X fungizone (Invitrogen, Carlsbad, CA), was added. After incubating for 10 days at $37^{\circ} \mathrm{C}, 5 \% \mathrm{CO}_{2}$, cells were fixed in $20 \%$ acetone $(\mathrm{v} / \mathrm{v})$ in phosphate buffered saline for
$15 \mathrm{~min}$ at room temperature and allowed to dry overnight. An immunoperoxidase staining protocol (Brodersen and Kelling, 1998) was performed which used the monoclonal antibody 8G12, specific for the F protein of BRSV (Klucas and Anderson, 1988), as the primary antibody and biotinylated horse anti-mouse immunoglobulin (Vector Laboratories, Burlingame, CA) as the secondary antibody. Antibody binding was detected using streptavidin horseradish peroxidase conjugate (Zymed, San Francisco, CA) and 3-amino-9-ethylcarbazole (Sigma, St. Louis, MO). All staining was done in duplicate.

\subsection{Synthesis of RNA standard}

Viral cDNA was synthesized by RT-PCR from BRSV 236-652 F protein, using forward primer $1029 \mathrm{~F}$ and reverse primer 1292R, and cloned into pCR 2.1 (Invitrogen, Carlsbad, CA) according to the manufacturer's directions. Plasmid DNA containing the BRSV F coding region was isolated from transformed bacteria using the Wizard ${ }^{\circledR}$ Plus Minipreps DNA purification system (Promega, Madison, WI) according to the manufacturer's directions. Plasmid DNA was digested with restriction endonucleases KpnI and XbaI (Invitrogen, Carlsbad, CA) followed by agarose gel electrophoresis and visualization of digested products by ethidium bromide staining to verify the correct DNA insertion. The proper DNA sequence was confirmed further by automated sequencing (Genomics Core Facility, UNL, Lincoln, NE). The DNA insert was modified by addition of a $30 \mathrm{bp}$ T-7 promoter using PCR with the forward primer, T7-1029F, and reverse primer, 1292R. This resulted in an amplified region of $264 \mathrm{bp}$ (not including the T7 promotor) to be used in an in vitro transcription reaction. The T7-promoter modified PCR product was used to transcribe the cDNA to cRNA in the presence of $\left[\mathrm{a}^{-}{ }^{32} \mathrm{P}\right] \mathrm{ATP}$ using the RT-PCR Competitor Construction Kit (Ambion, Austin, TX) according to the manufacturer's directions. The concentration of the standard was determined by measuring the counts per minute $(\mathrm{cpm}) / \mu \mathrm{l}$ of the purified competitor RNA and the $\mathrm{cpm} / \mu \mathrm{l}$ of the transcription reaction using a Wallac 1410 scintillation counter according to the manufacturer's directions. The standard concentration was determined to be $1.71 \times 10^{8}$ copies $/ \mu$ l and was stored at $-20{ }^{\circ} \mathrm{C}$ until used for Q-RT-PCR. Serial dilutions of the standard concentration were prepared and used for generation of the standard curve during Q-RT-PCR.

\subsection{Synthesis of RNA competitor}

The same BRSV cDNA prepared from the F protein of BRSV 236-652 using PCR as previously described in Section 2.4 was used for RNA competitor construction. Restriction endonuclease digestions were then performed using restriction endonucleases, $\mathrm{MfeI}$ and $\mathrm{Bs} r \mathrm{GI}$ (New England Biolabs, Beverly, MA) to excise a $45 \mathrm{bp}$ segment 
Table 1. Sequences of primers and probe for real-time Q-RT-PCR and QC-RT-PCR

\begin{tabular}{|c|c|c|}
\hline Primer/probe & Position on BRSV F coding region & Composition \\
\hline BRSV-probe & 1113-1143 & М-СTCTGCCTACTGATGTTAACTTATGCAACAC-3'-TAMRA-3' \\
\hline $1085 \mathrm{~F}$ & $1085-1104$ & STTCTGTGACACAATGAA-3' \\
\hline $1210 \mathrm{R}$ & $1191-1210$ & CAGAGCTACTTATATCAG-3' \\
\hline $1292 \mathrm{R}$ & 1273-1292 & 'TTATGATTCCACGATTT-3' \\
\hline $1029 \mathrm{~F}$ & 1029-1047 & GGCTCTGTGTCTTTTTT-3' \\
\hline T7-1029F & 1029-1047 & GTAATACGACTCACTATAGGGAGAGGAGCAGGCTCTGTGTCTTTTTT-3' \\
\hline
\end{tabular}

Underlined sequence is T-7 promoter sequence.

from the BRSV F protein coding region. The ends were digested with Mung Bean nuclease (New England Biolabs, Beverly, MA) and re-ligated. The modified DNA sequence was confirmed by automated sequencing (Genomics Core Facility, UNL, Lincoln, NE). PCR was then performed on the plasmid DNA, with the deletion, using forward primer T7-1029F and reverse primer 1292R. The T7-modified PCR product was then used to transcribe the cDNA into cRNA using the RT-PCR Competitor Construction Kit (Ambion, Austin, TX). Competitor concentration was determined to be $7.41 \times 10^{7}$ copies $/ \mu 1$ (see Section 2.4) and was stored at $-20^{\circ} \mathrm{C}$ until used for QC-RT-PCR.

\subsection{Primers and probe}

Primer and probe sequences were designed based on sequence homology of the $\mathrm{F}$ protein among six different BRSV strains that were aligned using Wisconsin package version 10.2, Genetics computer group (GCG, Madison, WI) and using the parameters outlined by the TaqMan probe design. The BRSV probe was labeled with a fluorescent reporter dye (6-carboxyfluorescein, FAM) at the 5 ' end with a quencher dye (6-carboxytetramethylrhodamine, TAMRA) at the $3^{\prime}$ end (Qiagen, Alameda, CA). Sequences of primers and probe are listed in Table 1.

\subsection{Real-time Q-RT-PCR}

The real-time Q-RT-PCR was performed in single wells of a 96-well plate (BioRad, Hercules, CA) in a $25 \mu \mathrm{l}$ reaction volume using components of the AccessQuick ${ }^{\mathrm{TM}}$ RT-PCR system (Promega, Madison, WI). The $25 \mu \mathrm{l}$ reaction mixture contained, $12.5 \mu$ l AccessQuick ${ }^{\mathrm{TM}}$ master $\operatorname{mix}(2 \mathrm{X}), 2.5 \mu \mathrm{l}$ of $3 \mu \mathrm{M}$ forward primer, (1085F), $2.5 \mu 1$ of $3 \mu \mathrm{M}$ reverse primer (1210R), $1 \mu \mathrm{l}$ of $2 \mu \mathrm{M}$ fluorogenic probe, $3 \mu \mathrm{l}$ of $\mathrm{ddH}_{2} \mathrm{O}, 1 \mu \mathrm{l} 50 \mathrm{mM} \mathrm{MgCl}{ }_{2}, 0.5 \mu \mathrm{l}$ of AMV RT ( $5 \mathrm{U} / \mu \mathrm{l})$, and $2 \mu \mathrm{l}$ of BRSV RNA sample. The RT-PCR thermocycling program consisted of $50^{\circ} \mathrm{C}$ for $30 \mathrm{~min}$, $95^{\circ} \mathrm{C}$ for $5 \mathrm{~min}$, followed by 35 cycles of $95^{\circ} \mathrm{C}$ for $15 \mathrm{~s}$ and $55^{\circ} \mathrm{C}$ for $50 \mathrm{~s}$. Both reverse transcription and PCR were carried out in the same well of a 96-well plate using the $\mathrm{iCycler}_{\mathrm{i}} \mathrm{Q}^{\mathrm{TM}}$ (BioRad, Hercules, CA).

Fluorescence was measured following each cycle and displayed graphically (iCycler iQ Real-time Detection
System Software, version 2.3, BioRad, Hercules, CA). The software determined a cycle threshold $(\mathrm{Ct})$ value, which identified the first cycle at which the fluorescence was detected above the baseline for that sample or standard. The standard curve, $\mathrm{Ct}$ values versus starting standard mRNA amounts, was used to determine initial starting quantity of BRSV mRNA from each time point based on the Ct values of the BRSV samples.

\subsection{Quantitative competitive RT-PCR}

QC-RT-PCR was performed in a single tube using the same AccessQuick ${ }^{\mathrm{TM}}$ master mix. The reaction mixture consisted of $12.5 \mu \mathrm{l}$ of master mix, $2.5 \mu \mathrm{l}$ of $3 \mu \mathrm{M}$ forward primer $(1085 \mathrm{~F}), 2.5 \mu \mathrm{l}$ of $3 \mu \mathrm{M}$ reverse primer, (1292R), $5 \mu \mathrm{l}$ of $\mathrm{ddH}_{2} \mathrm{O}, 0.5 \mu \mathrm{l}$ of AMV RT $(5 \mathrm{U} / \mu \mathrm{l}), 1 \mu \mathrm{l}$ of unknown RNA, and $1 \mu \mathrm{l}$ of RNA competitor with known concentration. The RT-PCR thermocycling program consisted of $48{ }^{\circ} \mathrm{C}$ for $30 \mathrm{~min}, 95^{\circ} \mathrm{C}$ for $5 \mathrm{~min}$, followed by 35 cycles of $95^{\circ} \mathrm{C}$ for $1 \mathrm{~min}, 55^{\circ} \mathrm{C}$ for $1 \mathrm{~min}$, $72{ }^{\circ} \mathrm{C}$ for $2 \mathrm{~min}$, followed by a $10 \mathrm{~min}$ extension cycle of $72^{\circ} \mathrm{C}$. Both reverse transcription and PCR were carried out in the same tube using the Perkin Elmer Cetus, DNA Thermal Cycler (Perkin Elmer, Shelton, CT). Amplified samples were then electrophoresed in a $2 \%$ agarose gel for $75 \mathrm{~min}$. Following ethidium bromide staining, bands were visualized and relative intensities determined using Kodak Digital Science ${ }^{\mathrm{TM}}$ 1D software (Eastman Kodak Co., Rochester, NY).

\subsection{Statistical analysis}

Analysis of variance (ANOVA) was performed on eight mRNA values (duplicate samples of four extractions) for each time point to assess the reproducibility of the real-time assay, except where seven observations were made at time points 12 and $24 \mathrm{~h}$. Reproducibility was evaluated with the coefficient of variation based on the error variance from the ANOVA on the real-time Q-RT-PCR values. A two-sample $t$-test, using the mean square error from the ANOVA on the QRT-PCR was used to compare means of real-time QRT-PCR, QC-RT-PCR and viral titer at each time point post-infection. 


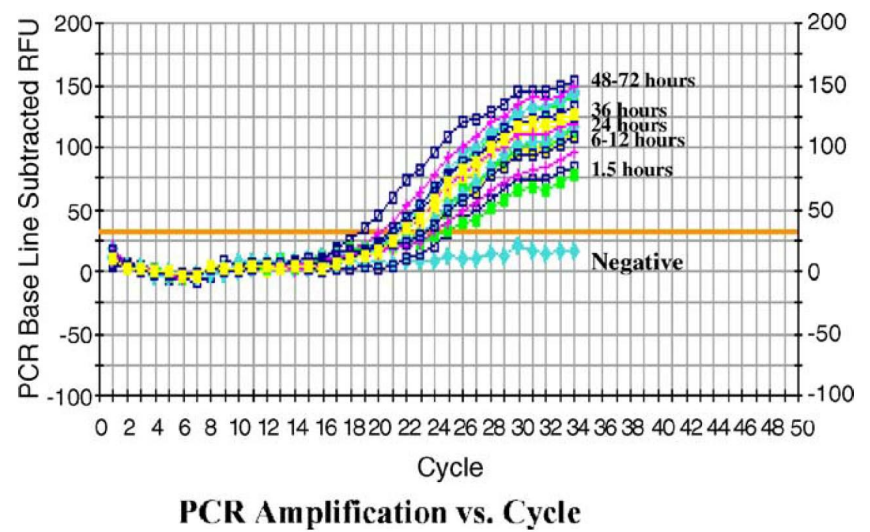

Figure 1. Amplification plot of real-time Q-RT-PCR of BRSV samples at each time-point. A typical amplification plot is shown with the negative control remaining below the baseline. The $y$-axis represents the PCR base line subtracted RFU (relative fluorescence units) with the baseline being set at 2-10 cycles. Cycle number is displayed on the $x$-axis.

\section{Results and discussion}

This study was conducted to detect BRSV and to measure levels of viral mRNA in BRSV-infected cell cultures using real-time Q-RT-PCR. Real-time Q-RT-PCR viral mRNA levels were compared to QC-RT-PCR and viral titers using a time course assay of virus infection including eight time points $(1.5,6,12,24,36,48,60,72 \mathrm{~h})$ post-infection.

\subsection{Real-time $Q-R T-P C R$}

Amplification plots and standard curves were generated upon completion of the Q-RT-PCR reaction (Figure 1 and Figure 2). The standard curve, with a slope of -2.992 and a correlation coefficient of 0.971 , was created from 10-fold serial dilutions of the standard cRNA from $10^{7}$ to $10^{3}$ copies/reaction. Standard input copy numbers were plotted against the $\mathrm{Ct}$ values, which were between
Table 2. Reproducibility of real-time Q-RT-PCR

\begin{tabular}{lcc}
\hline $\begin{array}{l}\text { Hours, } \\
\text { post-infection }\end{array}$ & $\begin{array}{c}\text { log mRNA copies/ml } \\
\text { range (mean) }\end{array}$ & $\begin{array}{c}\text { Cycle threshold } \\
\text { range (mean) }\end{array}$ \\
\hline 1.5 & $5.61-7.88(7.05)$ & $20.93-27.15(24.26)$ \\
6 & $5.17-7.80(7.05)$ & $20.87-26.39(24.18)$ \\
12 & $4.88-7.77(6.20)$ & $22.62-32.04(26.35)$ \\
24 & $5.88-7.81(7.06)$ & $21.33-29.13(24.18)$ \\
36 & $7.57-9.14(8.19)$ & $18.32-22.08(20.52)$ \\
48 & $7.44-8.98(8.36)$ & $18.71-21.69(20.03)$ \\
60 & $7.43-8.51(8.16)$ & $19.02-22.77(20.71)$ \\
72 & $7.78-9.10(8.65)$ & $18.40-20.74(19.37)$ \\
\hline
\end{tabular}

14 and 28 cycles. The sensitivity of this assay was as low as 171 copies. All BRSV infected samples from each time point $(1.5-72 \mathrm{~h})$ tested positive with mean $\mathrm{Ct}$ values ranging from 20 to 25 cycles, showing that all samples were within the range of the standard $\mathrm{Ct}$ values.

Results of the Q-RT-PCR were highly reproducible (coefficient of VARIATION $=10.4 \%$ ) based on ANOVA of mRNA values for each time point (Table 2). This is consistent with the high reproducibility of the TaqMan assay results for quantitation of hepatitis $C$ virus (Puig et al., 2002).

\subsection{QC-RT-PCR}

Following QC-RT-PCR, products were resolved in a $2 \%$ agarose gel followed by ethidium bromide staining. Relative intensities of bands were evaluated using the Kodak Digital Science ${ }^{\mathrm{TM}} 1 \mathrm{D}$ software. Values were compared to determine the point of equal amplification (Figure 3). BRSV mRNA measured by QC-RT-PCR was comparable to the amount of BRSV mRNA determined by real-time Q-RT-PCR at the time points evaluated (Table 3).

\subsection{Virus titration}

The $\mathrm{TCID}_{50} / \mathrm{ml}$ of BRSV-infected cells, harvested at each time point post-infection, were determined in duplicate. BRSV titers were $10^{2.8} \mathrm{TCID}_{50} / \mathrm{ml}$ at $1.5 \mathrm{~h}$ post-infection

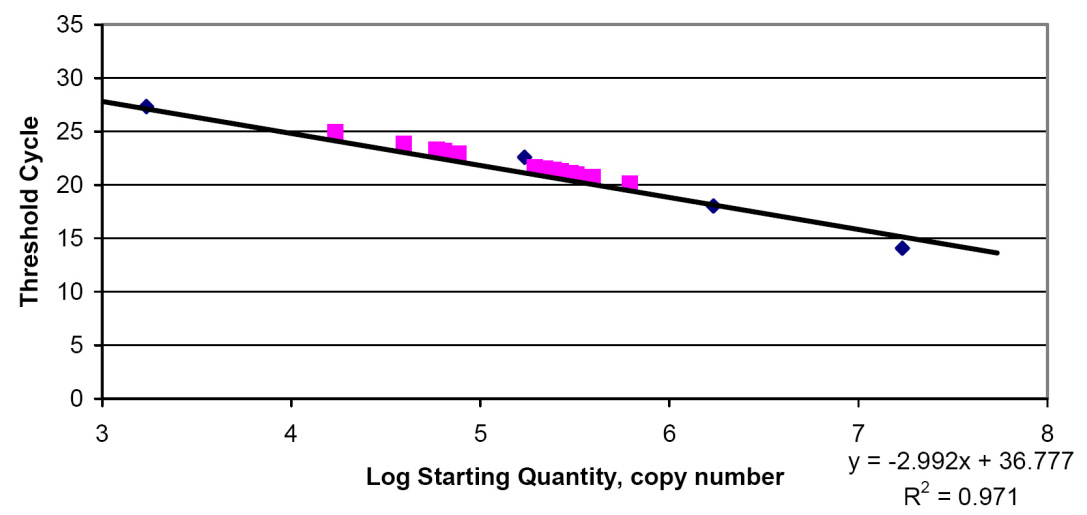

Figure 2. Standard curve of a BRSV Q-RT-PCR assay. Serial 10-fold dilutions of in vitro transcribed standard BRSV cRNA (1.71 $\times$ $10^{7}-1.71 \times 10^{3}$ copies $\left./ \mu l\right)$ were plotted against the threshold cycle. The quantity of unknown BRSV RNA in samples was then determined by comparing the cycle threshold of the sample to the standard curve. The unknowns are duplicates of BRSV-infected cell culture from 1.5 to $72 \mathrm{~h}$. ( $\downarrow)$ Represents standard cRNA samples, (•) represents BRSV RNA samples. 
Table 3. BRSV viral titers, real-time Q-RT-PCR and QC-RTPCR log mRNA copies/ $\mathrm{ml}$ at each time point post-infection

\begin{tabular}{lccc}
\hline $\begin{array}{l}\text { Hours, } \\
\text { post- } \\
\text { infection }\end{array}$ & $\begin{array}{l}\text { Viral titer log } \\
\mathrm{TCID}_{50} / \mathrm{ml}\end{array}$ & $\begin{array}{l}\text { Real-time } \\
\text { Q-RT-PCR } \\
\text { log mRNA } \\
\text { copies/ml }\end{array}$ & $\begin{array}{c}\text { C-RT-PCR log } \\
\text { mRNA copies/ml }\end{array}$ \\
\hline 1.5 & 2.8 & 7.05 & 7.48 \\
6 & 2.6 & 7.05 & 7.36 \\
12 & 2.6 & 6.20 & 7.27 \\
24 & 2.9 & 7.06 & 7.57 \\
36 & 3.7 & 8.19 & 7.87 \\
48 & 4.1 & 8.36 & 8.00 \\
60 & 3.8 & 8.16 & 7.97 \\
72 & 3.9 & 8.65 & 8.27 \\
\hline
\end{tabular}

and $10^{3.9} \mathrm{TCID}_{50} / \mathrm{ml}$ at the conclusion of the time course assay (72 $\mathrm{h}$ post-infection). The BRSV titer dropped to its lowest value $\left(10^{2.6} \mathrm{TCID}_{50} / \mathrm{ml}\right)$ at 6 and $12 \mathrm{~h}$ post-infection and reached its highest value $\left(10^{4.1} \mathrm{TCID}_{50} / \mathrm{ml}\right)$ at $48 \mathrm{~h}$ post-infection (Table 3 ).

\subsection{Comparison of methods}

BRSV mRNA levels determined by real-time Q-RT-PCR and by QC-RT-PCR assays were plotted against viral titers at each time point post-infection (Figure 4). To compare viral titers and QC-RT-PCR assay results with realtime Q-RT-PCR assay results, we assumed the error of variance for the Q-RT-PCR assay was the same as the viral titer and QC-RT-PCR assay and used a two-sample $t$ test. It was found that viral titers differed significantly $(P<0.05)$ from QC-RT-PCR and Q-RT-PCR assay results at all time points, post-infection. The results of QC-RTPCR and Q-RT-PCR assays were comparable since there were no significant differences between mRNA levels from real-time Q-RT-PCR and QC-RT-PCR assays at all time points, except $12 \mathrm{~h}$ post-infection $(P<0.05)$. This was evidence that the real-time Q-RT-PCR BRSV assay is an accurate, reproducible assay. The assay is also time-efficient and can be used to advantage to replace traditional techniques such as virus titration and QCRT-PCR. mRNA levels determined by either assay were significantly higher than viral titers, but the pattern of

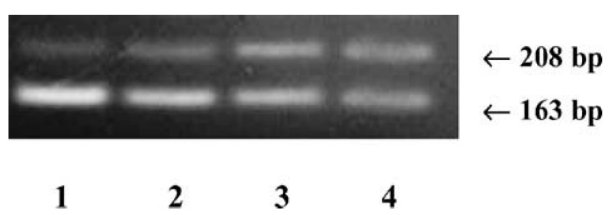

Figure 3. BRSV QC-RT-PCR ethidium bromide stained gel at $48 \mathrm{~h}$ post-infection. Each lane shows amplification of the BRSV sample at $208 \mathrm{bp}$ with the BRSV competitor at $163 \mathrm{bp}$. Each reaction is comprised of $1 \mu \mathrm{l}$ of BRSV RNA sample plus $1 \mu \mathrm{l}$ of competitor cRNA (copies/ml) at differing concentrations. Relative intensities of bands were analyzed using Kodak Digital Science 1D software. At $48 \mathrm{~h}$ post-infection (copies $/ \mathrm{ml}$ ): Lane $13.7 \times 10^{8}$; Lane $21.85 \times 10^{8}$; Lane $31.0 \times 10^{8}$; and Lane 49.25 $\times 10^{7}$. The bands were equal in intensity in Lane 3 with the amount of $48 \mathrm{~h}$ BRSV mRNA being $1.0 \times 10^{8}$ copies $/ \mathrm{ml}$. Similar methods were done for the quantitation of viral mRNA in samples from each time point.

values obtained from each of the three assays over the infection time course correlated closely. This is consistent with a previous report by Garcia et al. (2001), which showed that viral titers were lower when compared to mRNA levels obtained by real-time Q-RT-PCR assay of rift valley fever virus (RVFV) in cell culture and mouse sera. In that study, during a time course of RVFV infection, viral titers of infected cell culture ranged from 1.7 to $6.0 \mathrm{TCID}_{50} / \mathrm{ml}$ and were significantly lower at the same time points post-infection than real-time Q-RTPCR values, which ranged from 5.1 and 9.0 log RNA copies $/ \mathrm{ml}$. They also concluded that the difference in viral titers and real-time Q-RT-PCR values could be due to the presence of non-infectious viral RNA, or over-expression of the RVFV S segment in the cells. Similarly in our study, the comparatively higher levels of BRSV mRNA compared to BRSV titers, could be attributable to the presence of non-infectious BRSV RNA or due to the over-expression of BRSV F RNA in the infected cells.

Development of the real-time Q-RT-PCR assay for BRSV, described in this report, is significant because the assay is sensitive and reproducible so that it will be useful for diagnostic applications. The assay is also efficient since use of test plates specifically designed for the iCycler $\mathrm{iQ}^{\mathrm{TM}}$ allowed assay of up to 384 samples/plate. The

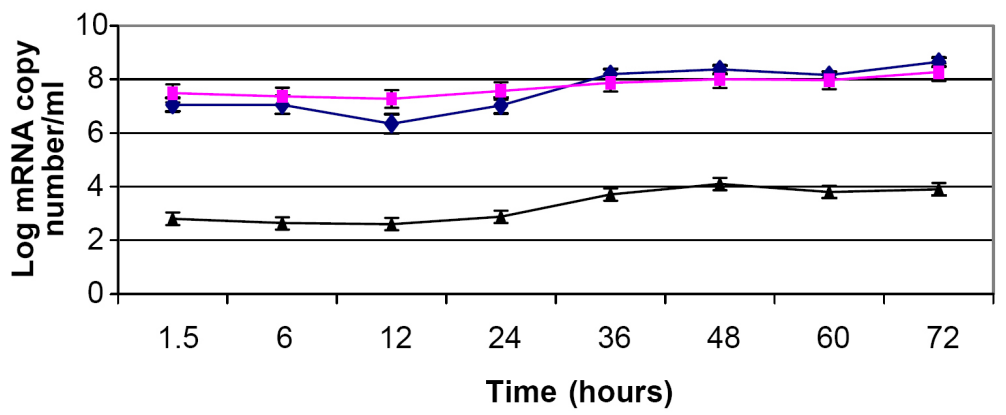

Figure 4. Comparison of the amounts of viral mRNA determined by real-time Q-RT-PCR or QC-RT-PCR, with virus titers (Log $\left.\mathrm{TCID}_{50}\right)$. Values were not significantly different between real-time Q-RT-PCR and QC-RT-PCR at all time points except $12 \mathrm{~h}$ postinfection. There was a correlation between all three methods showing the same pattern of values. ( $\downarrow)$ Represents Real-time Q-RTPCR, $(\square)$ represents QC-RT-PCR, $(\boldsymbol{\Delta})$ represents Viral titer. 
software facilitated relaying positive assay results after completion of minimal cycles. Those assay features are desirable when large numbers of samples are tested with time limitations. Real-time RT-PCR procedures have been recently adapted for diagnostic applications to detect other viral infections, which include: bovine viral diarrhea virus (BVDV) (Bhudevi and Weinstock, 2001 and Mahlum et al., 2002), foot and mouth disease virus (Callahan et al., 2002), porcine endogenous retrovirus (Argaw et al., 2002), and rotavirus (Schwarz et al., 2002). Real-time RT-PCR assays were shown to be most efficient and sensitive for assay of clinical specimens infected with BVDV, when compared to gel-based RT-PCR assays, virus isolation tests, immunoperoxidase monolayer assays, and immunohistochemistry assays. Gelbased RT-PCR was more sensitive than cell culture virus isolation tests, but gel-based PCR results can be compromised by contamination during nucleic acid amplification. Contamination during amplification is avoided by using real-time RT-PCR assays. (Bhudevi and Weinstock, 2003 and Mahlum et al., 2002).

The adaptability of real-time RT-PCR assays was demonstrated when a portable real-time system was used to detect foot-and-mouth disease virus (FMDV) in the field. All seven serotypes of FMDV grown in tissue culture were detected with viral RNA detectable 24-96 h before development of clinical signs. The efficiency of the assay in this application was evident when test results were available within two hours (Callahan et al., 2002).

Real-time Q-RT-PCR has also been used in disease pathogenesis studies to determine viral load and viral gene expression. Real-time Q-RT-PCR was five orders of magnitude more sensitive than Northern dot blot hybridization for determining viral load in spinal cords of mice infected with Theiler's virus. The high sensitivity of real-time Q-RT-PCR was clearly evident when as few as 20-30 copies of Theiler's virus RNA copy equivalents were detectable (Trottier et al., 2002).

In summary, the real-time Q-RT-PCR and QC-RTPCR assays described can be used reliably to detect BRSV and measure BRSV mRNA levels in infected cell cultures with comparable results. The Q-RT-PCR assay is sensitive, specific, rapid and efficient, eliminating the post-PCR processing steps required for QC-RT-PCR. The Q-RT-PCR assay may be applied, with advantage, to measuring viral mRNA levels in tissues of BRSV-infected calves in diagnostic testing or in experimental studies directed toward understanding the pathogenesis of BRSV-induced disease.

\section{References}

Argaw, T., Ritzhaupt, A. and Wilson, C., 2002. Development of a realtime quantitative PCR assay for detection of porcine endogenous retrovirus. J. Virol. Meth. 106, pp. 97-106.

Bhudevi, B. and Weinstock, D., 2001. Fluorogenic RT-PCR assay (TaqMan) for detection and classification of bovine viral diarrhea virus. Vet. Microbiol. 83, pp. 1-10.
Bhudevi, B. and Weinstock, D., 2003. Detection of bovine viral diarrhea virus in formalin fixed paraffin embedded tissue sections by real-time RT-PCR (TaqMan). J. Virol. Meth. 109, pp. 25-30.

Brodersen, B. and Kelling, C., 1998. Effect of concurrent experimentally induced bovine respiratory syncytial virus and bovine viral diarrhea virus infection on respiratory tract and enteric disease in calves. Am. J. Vet. Res. 59, pp. 1423-1430.

Callahan, J.D., Brown, F., Osorio, F., Sur, J., Kramer, E., Long, G., Lubroth, J., Ellis, S., Shoulars, K., Gaffney, K., Rock, D. and Nelson, W., 2002. Use of a portable real-time reverse transcriptase-polymerase chain reaction assay for rapid detection of foot-and-mouth disease virus. J. Am. Vet. Med. Assoc. 220, pp. 1636-1642.

Garcia, S., Crance, J., Billecocq, A., Peinnequin, A., Jouan, A., Bouloy, M. and Garin, D., 2001. Quantitative real-time PCR detection of rift valley fever virus and its application to evaluation of antiviral compounds. J. Clin. Microbiol. 39, pp. 4456-4461.

Hazari, S., Prada, H., Kar, B. and Das, B., 2002. Comparative evaluation of indirect and sandwich ELISA for the detection of antibodies to bovine respiratory syncytial virus (BRSV) in dairy cattle. Comp. Immunol. Microbiol. Infect. Dis. 25, pp. 59-68.

Huang, Y. and Wertz, G., 1982. The genome of respiratory syncytial virus is a negative-stranded RNA that codes for at least seven mRNA species. J. Virol. 43, pp. 150-157.

Klucas, C. and Anderson, G., 1988. Bovine respiratory syncytial virusspecific monoclonal antibodies. Vet. Immunol. Immunopathol. 18, pp. 307-315.

Lerch, R., Stott, E. and Wertz, G., 1989. Characterization of bovine respiratory syncytial virus proteins and mRNAs and generation of cDNA clones to the viral mRNAs. J. Virol. 63, pp. 833-840.

Mahlum, C.E., Haugerud, S., Shivers, J.L., Rossow, K.D., Goyal, S.M., Collins, J.E. and Faaberg, K.S., 2002. Detection of bovine viral diarrhea virus by TaqMan ${ }^{\circledR}$ reverse transcription polymerase chain reaction. J. Vet. Diagn. Invest. 14, pp. 120-125.

Murphy, F., Famfuet, C., Bishop, D., Ghabrial, S., Jarvis, A., Martelli, G., Mayo, M. and Summers, M., 1995. Virus taxonomy, sixth report on taxonomy of the international committee on taxonomy of viruses. Arch. Virol. Supplement 10, pp. 268-274.

Oberst, R., Hays, M., Evermann, J. and Kelling, C., 1993. Characteristic differences in reverse transcription-polymerase chain reaction products of ovine, bovine, and human respiratory syncytial viruses. J. Vet. Diagn. Invest. 5, pp. 322-328.

Oberst, R., Hays, M., Hennessy, K., Stine, L., Evermann, J. and Kelling, C., 1993. Identifying bovine respiratory syncytial virus by reverse transcription-polymerase chain reaction and oligonucleotide hybridizations. J. Clin. Microbiol. 31, pp. 1237-1240.

Puig, M., Mihalik, K., Yu, M., Feinstone, S. and Major, M., 2002. Sensitivity and reproducibility of HCV quantitation in chimpanzee sera using TaqMan real-time PCR assay. J. Virol. Meth. 105, pp. 253-263.

Schwarz, B., Bange, R., Vahlenkamp, T., Johne, R. and Muller, H., 2002. Detection and quantitation of group A rotaviruses by competitive and real-time reverse transcription-polymerase chain reaction. J. Virol. Meth. 105, pp. 277-285.

Trottier, M., Schlitt, B. and Lipton, H., 2002. Enhanced detection of Theiler's virus RNA copy equivalents in the mouse central nervous system by real-time RT-PCR. J. Virol. Meth. 103, pp. 89-99.

Valarcher, J., Bourhy, H., Gelfi, J. and Schelcher, F., 1999. Evaluation of a nested reverse transcription-PCR assay based on the nucleoprotein gene for diagnosis of spontaneous and experimental bovine respiratory syncytial virus infections. J. Clin. Microbiol. 37, pp. 1858-1862.

West, K., Bogdan, J., Hamel, A., Nayar, G., Morley, P., Haines, D. and Ellis, J., 1998. A comparison of diagnostic methods for the detection of bovine respiratory syncytial virus in experimental clinical specimens. Can. J. Vet. Res. 62, pp. 245-250. 